(c) 2018 - ISSN 1807-2577

\title{
Influence of cavo superficial enamel acid-etching on the microtensile bond strength of low-shrinkage composite resin
}

\author{
Influência do condicionamento ácido do ângulo cavo superficial na resistência \\ adesiva de restaurações em um compósito de baixa contração de \\ polimerização
}

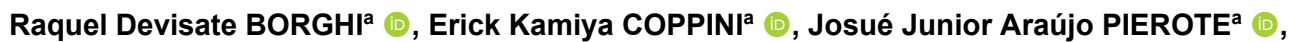
João Victor Frazão CÂMARA ${ }^{b *}$ (1), Luis Alexandre Maffei Sartini PAULILLO ${ }^{a}$ (1)

aUNICAMP - Universidade Estadual de Campinas, Faculdade de Odontologia de Piracicaba, Piracicaba, SP, Brasil bUSP - Universidade de São Paulo, Faculdade de Odontologia de Bauru, Bauru, SP, Brasil

\begin{abstract}
How to cite: Borghi RD, Coppini EK, Pierote JJA, Câmara JVF, Paulillo LAMS. Influence of cavo superficial enamel acid-etching on the microtensile bond strength of low-shrinkage composite resin. Rev Odontol UNESP. 2020;49:e20200022.

https://doi.org/10.1590/1807-2577.02220
\end{abstract}

\begin{abstract}
Resumo
Introdução: Com o intuito de se evitar as tensões geradas durante a contração de polimerização das resinas compostas, foram desenvolvidas as resinas compostas de baixa contração de polimerização. Objetivo: Avaliar a resistência à microtração em cavidades classe I restauradas com tratamento ácido do ângulo cavo superficial e resina composta indicada para dentes posteriores. Material e método: Foram selecionados 48 molares hígidos que foram divididos em 6 grupos $(n=8)$, sendo que 3 desses tiveram o esmalte cavo superficial condicionado com ácido fosfórico a 35\%. Os dentes foram restaurados com o sistema adesivo Clearfil SE Bond e as resinas compostas Filtek Z350 XT, Empress Direct e Charisma Diamond, fotoativadas por 40 segundos. Após 24 horas, os dentes foram levados para máquina de corte, na qual foram realizados cortes no sentido vestíbulo-lingual e no sentido mésio-distal obtendo - se palitos de 0,9×0,9 mm que foram levadas para a máquina de ensaio universal para a realização do teste de microtração. Para análise estatística foi realizado análise de variância e teste de Tuckey $(\mathrm{p}<0,05)$. Resultado: Não houve diferença estatística significante entre os grupos avaliados. Conclusão: 0 condicionamento ácido do ângulo cavo superficial não influenciou no desempenho das restaurações provavelmente devido ao sistema adesivo utilizado.
\end{abstract}

Descritores: Resinas compostas; preparo da cavidade dentária; dureza.

\begin{abstract}
Introduction: To prevent the shrinkage stresses produced during polymerization, composite resins of low polymerization shrinkage were developed. Objective: To evaluate the microtensile bond strength in class I cavities restored by acid-etching the cavosurface angle and with composite resins indicated for posterior teeth. Material and method: 48 healthy molars were selected and divided into six groups ( $\mathrm{n}=8$ ), considering that the cavosurface enamel of three groups was etched with $35 \%$ phosphoric acid. The teeth were restored with the Clearfil SE Bond adhesive system and Filtek Z350 XT, Empress Direct, and Charisma Diamond composite resins, which were light-cured for 40 seconds. After 24 hours, the teeth were taken to a cutting machine, which produced sections in the buccolingual and mesiodistal directions. This resulted in toothpicks of $0.9 \times 0.9 \mathrm{~mm}$ that were taken to the universal testing machine for the microtensile bond strength test. Statistical analysis was performed with ANOVA and Tukey's test $(\mathrm{p}<0.05)$. Result: There was no statistically significant difference between the groups evaluated. Conclusion: Acid-etching the cavosurface angle did not affect the performance of restorations, probably due to the adhesive system used.

Descriptors: Composite resins; dental cavity preparation; hardness.
\end{abstract}




\section{INTRODUCTION}

Composite resins were the material selected for the direct restorations due to their mechanical properties and especially their ability to mimic dental structures. Although presenting clinical success, the development of these materials is still required because polymerization shrinkage, which is an intrinsic characteristic of this material, may cause failures in the marginal sealing after the polymerization reaction, resulting in infiltrations ${ }^{1,2}$ and consequently postoperative sensitivity, marginal discolorations, and recurrent caries ${ }^{1,3}$.

To reduce stress in the adhesive interface, composite resins have been developed with lower polymerization shrinkage. The first composite resin developed with this characteristic was the siloxane-based composite resin. This resin has a different molecular structure from the methacrylate-based resins, considering it is composed of oxirane and siloxane monomers ${ }^{4}$. As a material with a different molecular structure, this composite resin requires using its own self-etching adhesive system ${ }^{5}$. However, this material is no longer available in the dental market.

To obtain a composite resin of low polymerization shrinkage, the methacrylate base was developed with the Charisma Diamond urethane-based resin. This resin presents a new functional monomer (TCD-DI-HEA) with the characteristics of associating low volumetric polymerization shrinkage with low viscosity ${ }^{5-7}$. This composite resin has shown less stress during polymerization when compared to the Filtek P90 composite resin ${ }^{8}$, which was the first low polymerization composite resin developed.

These materials require adhesive systems that can be bonded to the dental substrate, and they may be classified into two types: total-etch adhesive systems or self-etching adhesive systems. Self-etching systems are easier to handle and provide faster application ${ }^{9}$ and lower technical difficulties, reducing the possibility of errors during handling ${ }^{10}$. However, self-etching adhesive systems present poor enamel penetration ${ }^{11}$, which could lead to faster degradation of the tooth/restoration interface ${ }^{12,13}$.

To optimize the penetration of monomers of the adhesive system in the enamel, the selective acid etching of the cavosurface angle has been suggested to increase the longevity and quality of the tooth/restoration interface, improving the sealing ability of the restorative system ${ }^{14,15}$. In turn, acid-etching the dentin may cause poor bond strength in this substrate when using a self-etching adhesive system ${ }^{11}$. However, when a more effective bond to dentin is obtained by using self-etching adhesives, the shrinkage vector may be directed towards this substrate, increasing dentin stress.

Based on these factors, this study aimed to evaluate the influence of acid-etching the cavosurface angle of class I composite resin restorations on bond strength, using the Clearfil SE Plus adhesive system with methacrylate-based resins, considering one of them presented low polymerization shrinkage.

\section{MATERIAL AND METHOD}

The study was performed after the approval by the Human Research Ethics Committee, and the materials listed in Table 1 were used for this study. 
Table 1. Materials used in the study

\begin{tabular}{|c|c|c|}
\hline Trademark & Components & Manufacturer \\
\hline Scotchbond Acid & $\begin{array}{l}\text { 35\% phosphoric acid; water; poly (vinyl } \\
\text { alcohol) }\end{array}$ & $\begin{array}{l}\text { 3M Dental Products LTDA, Sumaré, } \\
\text { SP, Brazil }\end{array}$ \\
\hline $\begin{array}{l}\text { Clearfil SE Bond adhesive } \\
\text { system - Primer }\end{array}$ & $\begin{array}{c}10 \text { Methacryloyloxydecyl dihydrogen } \\
\text { phosphate (MDP); HEMA; Hydrophilic } \\
\text { dimethacrylate; Camphorquinone; Tertiary } \\
\text { amine; Water }\end{array}$ & $\begin{array}{l}\text { Kuraray Medical INC. Okayama, } \\
\text { Japan }\end{array}$ \\
\hline $\begin{array}{l}\text { Clearfil SE Bond - Bond } \\
\text { adhesive system }\end{array}$ & $\begin{array}{l}\text { HEMA; } 10 \text { Methacryloyloxydecyl dihydrogen } \\
\text { phosphate (MDP); Bis-GMA; Hydrophilic } \\
\text { dimethacrylate; Tertiary amine; Silanized } \\
\text { colloidal silica; Camphorquinone }\end{array}$ & $\begin{array}{l}\text { Kuraray Medical INC. Okayama, } \\
\text { Japan. }\end{array}$ \\
\hline $\begin{array}{l}\text { Charisma Diamond OD } \\
\text { composite resin }\end{array}$ & $\begin{array}{l}\text { UDMA; TC-DI-HEA; BA-AL-F silicate glass; } \\
\qquad \text { YbF3; } \mathrm{SiO}_{2}\end{array}$ & Heraeus Kulzer, São Paulo SP, Brazil \\
\hline $\begin{array}{l}\text { Filtek Z350 XT (A3) } \\
\text { composite resin }\end{array}$ & $\begin{array}{l}\text { Bis-GMA; UDMA; Bis-EMA; Camphorquinone; } \\
\text { Zirconia/Silica }\end{array}$ & $\begin{array}{l}\text { 3M Dental Products LTDA, Sumaré, } \\
\text { SP, Brazil }\end{array}$ \\
\hline $\begin{array}{l}\text { IPS Empress Direct } \\
\text { composite resin (A3) }\end{array}$ & Ba-Al-SiO4 glass; YbF3 & Ivoclair, Barueri, SP, Brazil \\
\hline
\end{tabular}

In this study, 48 recently extracted third molars were used. They were stored for a maximum of 24 hours in a buffered $0.1 \%$ thymol solution at $37^{\circ} \mathrm{C}$ to clean the external surfaces with a 5-6 periodontal curette by scraping and sandblasting with sodium bicarbonate and water. After cleaning, the teeth were stored in distilled water until beginning cavity preparation.

The teeth were included in polystyrene resin to standardize the cavity preparations. Then, the occlusal surface was flattened in a polishing machine with 400 sandpaper, taking care not to reach the underlying dentin. After planning the occlusal surface, the teeth were taken to a standardizing machine for cavity preparation, in which class I preparation was performed with the following dimensions: $5 \mathrm{~mm}$ in the mesiodistal direction, $4 \mathrm{~mm}$ in the buccolingual direction, and $3 \mathrm{~mm}$ in depth. The preparations were performed with a \#56 carbide drill, which was replaced every five preparations.

The mechanical microtensile test was performed with 48 human teeth restored with the Clearfil SE Bond/Composite Resins adhesive system, which were sectioned to obtain eight toothpicks $(0.9 \times 0.9 \mathrm{~mm}$ of area and $4 \mathrm{~mm}$ in length $)$ per tooth. Then, a draw was performed, obtaining one toothpick per tooth, that is, 48 toothpicks divided into six groups $(n=8)$ : Groups CDC (restored with Charisma Diamond), ZXC (restored with Filtek Z350 XT), and EDC (restored with IPS Empress Direct) had the cavosurface angle etched with phosphoric acid; and groups CDA (restored with Charisma Diamond), ZXA (restored with Filtek Z350 XT), and EPA (restored with IPS Empress Direct) did not have the cavosurface angle etched.

In half of the samples, randomized by draw, the cavosurface angle was acid-etched with $35 \%$ phosphoric acid for 30 seconds, then, the surface was washed with abundant water for 30 seconds and dried with air blasts.

Enamel and dentin were dried, then, two layers of primer were actively applied to dentin for 20 seconds and they were dried with a mild air blast for 10 seconds at a distance of 10 centimeters. A uniform layer of adhesive was applied for 20 seconds and polymerized for 10 seconds.

The teeth were restored with the Charisma Diamond, Filtek Z350 XT, and IPS Empress Direct composite resins in six increments. Each increment was photoactivated for 40 seconds with a Raddi Cal LED light fixture. After preparation, the samples were maintained in an environment with relative humidity at $37^{\circ} \mathrm{C}$ for 24 hours.

For the microtensile test, the dental crowns were separated from the root portion by sectioning perpendicularly to the long axis of the tooth, using a double-sided diamond disc. 
The crowns were fixed on acrylic plates with sticky wax. The set was fixed on the precision metallographic cutter, in which a high-concentration diamond disc rotating at low speed and under constant irrigation made serial cuts perpendicularly along the crown axis. Five sections were made in the buccolingual direction and four in the mesiodistal direction, obtaining $0.9 \times 0.9 \mathrm{~mm}$ toothpicks from the bonding interface of the pulp wall. The toothpicks were maintained in a relative humidity environment until the microtensile test was performed.

The toothpicks from the same tooth were taken to the universal testing machine and the test was conducted with a $20-\mathrm{N}$ load cell at a speed of $0.5 \mathrm{~mm} / \mathrm{min}$, until rupture. The force required to rupture the specimens, in kilogram-force (kgf), was noted and the dimensions of the adhesive interface of the specimens were measured with a digital caliper to calculate the area. The fracture strength, in Mega Pascal (MPa), was calculated according to the mathematical formula:

$$
R=F(k g f) \times 0.098 / A
$$

$\mathrm{R}=$ bond strength in $\mathrm{MPa} ; \mathrm{F}=$ force in kilogram-force (kgf); and $\mathrm{A}=$ area in $\mathrm{cm}^{2}$.

Tukey's test was performed at a 5\% probability, considering the analysis of variance already determined no significant difference.

\section{RESULT}

The result of the analysis of variance showed that the acid etching factor was not significant and the interaction between the factors of acid etching and composite resin was also not significant (Table 2).

Table 2. Result of the analysis of variance for the microtensile test

\begin{tabular}{ccc}
\hline Group & Mean (MPa) & Tukey's test \\
\hline CDC & 21.07 & $\mathrm{~A}$ \\
ZXC & 19.85 & $\mathrm{~A}$ \\
EDC & 21.00 & $\mathrm{~A}$ \\
CDA & 21.41 & $\mathrm{~A}$ \\
ZXA & 19.33 & $\mathrm{~A}$ \\
EPA & 19.64 & $\mathrm{~A}$ \\
\hline
\end{tabular}

\section{DISCUSSION}

The two-bottle self-etching adhesives present a satisfactory clinical performance in the dentin substrate and poor adhesion to enamel ${ }^{9,16}$. However, in the case of selective etching, there is an increase in bond strength in this region ${ }^{17}$, along with better marginal sealing and less crack formation ${ }^{18,19}$, consequently improving the quality of the bonding interface. Nevertheless, the present study did not show statistically significant differences between the groups studied.

This has probably occurred due to the adhesive system used in the study. This adhesive has a monomer that can perform an intense and stable chemical interaction with the remaining hydroxyapatite to improve adhesion: 10-methacryloyloxydecyl dihydrogen phosphate (10-MDP) ${ }^{20}$. This component has a strong interaction with dental tissues because its structure includes an acidic functional group. This interaction has shown better resistance to degradation, preventing the formation of micro- and nano-infiltrations ${ }^{9,21,22}$. It has also been observed that this monomer adheres firmly to hydroxyapatite, forming a salt that is difficult to dissolve in water ${ }^{21}$, increasing the number of cross-links and resin matrix resistance and decreasing polymerization shrinkage, reducing the possibility of microleakage ${ }^{22,23}$. 
The 10-MDP monomer appeared in the context of associating chemical adhesion with micromechanical adhesion, thus it was added to the primer and adhesive resin. Therefore, the main advantage of the 10-MDP monomer is increasing bond strength, improving the physical and chemical properties of self-etching adhesive systems, and stability in aqueous media. Moreover, it presents a different action mechanism, working as a conditioning agent in self-etching primers or adhesive resin solution, stimulating the amplification of the adhesive and working as a bonding agent. Besides the strong bond with the hydroxyapatite of enamel and dentin, the 10-MDP phosphate group can bond electrostatically with calcium ions, thus the acids present a chemical affinity to the hydroxyapatite calcium, promoting the release of phosphate ions and hydroxide (adhesion-decalcification concept). Therefore, adhesive systems with 10-MDP can form MDP-Ca salts, which have the following characteristics: stability, longevity, and resistance to hydrolysis 22,23 .

Yuan et al. ${ }^{24}$ evaluated the effectiveness of adhesive systems for nano-infiltration and reported that Clearfil SE bond (two steps) and Clearfil S3 Bond (single step), through electron microscopy analysis, showed greater sealing ability, and both contained 10-MDP in their compositions. By conducting two independent studies ${ }^{24}$, Couto et al. ${ }^{22}$ evaluated the marginal sealing of human molars after 24 hours and one year, with or without acid-etching the cavosurface angle, and found no significant difference at 24 hours, but the group of teeth etched with $37 \%$ phosphoric acid affected marginal microleakage after one year of storage in deionized water.

In this study, the Charisma Diamond resin was used, which showed no difference to the other composite resins. This resin has the TCD-urethane monomer, which according to the manufacturer, discards the use of diluting monomers and presents a molecule with three rings connected in a central portion, increasing the flexibility of the monomer and decreasing polymerization shrinkage ${ }^{6,25}$. This composite resin was expected to have better bonding properties due to such a characteristic, but this was not observed.

Further studies are required to assess the longevity of these restorations, analyzing whether this behavior is repeated after artificial aging.

\section{CONCLUSION}

Acid-etching the cavosurface angle did not affect the restorations performed with methacrylate-based composite resins (with or without low polymerization shrinkage), probably due to the adhesive system used.

\section{REFERENCES}

1. Calheiros FC, Sadek FT, Boaro LCC, Braga RR. Polymerization stress related to radiant exposure and its effect on microleakage of composite restorations. J Dent. 2007 Dec;35(12):946-52. http://dx.doi.org/10.1016/j.jdent.2007.09.009. PMid:17961901.

2. Cunha LG, Alonso RC, Souza-Junior EJ, Neves AC, Correr-Sobrinho L, Sinhoreti MA. Influence of the curing method on the post- polymerization shrinkage stress of a composite resin. J Appl Oral Sci. 2008 Jul-Aug;16(4):266-70. http://dx.doi.org/10.1590/S1678-77572008000400007. PMid:19089258.

3. Brandt WC, Moraes RR, Correr-Sobrinho L, Sinhoreti MAC, Consani S. Effect of different photoactivation methods on push out force, hardness and cross-link density of resin composite restorations. Dent Mater. 2008 Jun;24(6):846-50. http://dx.doi.org/10.1016/j.dental.2007.09.012. PMid:18045677.

4. Weinmann W, Thalacker C, Guggenberger R. Siloranes in dental composites. Dent Mater. 2005 Jan;21(1):68-74. http://dx.doi.org/10.1016/j.dental.2004.10.007. PMid:15681004. 
5. Santini A, Miletic V. Comparison of the hybrid layer formed by Silorane adhesive, one - step self-etch and etch and rinse systems using confocal micro-Raman spectroscopy an SEM. J Dent. 2008 Sep;36(9):683-91. http://dx.doi.org/10.1016/j.jdent.2008.04.016. PMid:18550251.

6. Boaro LCC, Gonçalves F, Guimarães TC, Ferracane JL, Versluis A, Braga RR. Polymerization stress, shrinkage and elastic modulus of current low- shrinkage restorative composites. Dent Mater. 2010 Dec;26(12):1144-50. http://dx.doi.org/10.1016/j.dental.2010.08.003. PMid:20832850.

7. Takahashi H, Finger WJ, Wegner K, Utterodt A, Komatsu M, Wöstmann B, et al. Factors influencing marginal cavity adaptation of nanofiller containing resin composite restorations. Dent Mater. 2010 Dec;26(12):1166-75. http://dx.doi.org/10.1016/j.dental.2010.08.189. PMid:20884047.

8. Marchesi G, Breschi L, Antoniolli F, Di Lenarda R, Ferracane J, Cadenaro M. Contraction stress of lowshrinkage composite materials assessed with different testing systems. Dent Mater. 2010 Oct;26(10):947-53. http://dx.doi.org/10.1016/j.dental.2010.05.007. PMid:20566212.

9. Van Meerbeek B, De Munck J, Yoshida Y, Inoue S, Vargas M, Vijay P, et al. Buonocore memorial lecture. Adhesion to enamel and dentin: current status and future challenges. Oper Dent. 2003 MayJun;28(3):215-35. PMid:12760693.

10. De Munck J, Van Landuyt K, Peumans M, Poitevin A, Lambrechts P, Braem M, et al. A critical review of the durability of adhesion to tooth tissue: Methods and results. J Dent Res. 2005 Feb;84(2):118-32. http://dx.doi.org/10.1177/154405910508400204. PMid:15668328.

11. Van Landuyt KL, Kanumilli P, De Munck J, Peumans M, Lambrechts P, Van Meerbeek B. Bond strength of a mild self-etch adhesive with and without prior acid-etching. J Dent. 2006 Jan;34(1):77-85. http://dx.doi.org/10.1016/j.jdent.2005.04.001. PMid:15979226.

12. Knobloch LA, Gailey D, Azer S, Johnston WM, Clelland N, Kerby RE. Bond strengths of one- and two-step self-etch adhesive systems. J Prosthet Dent. 2007 Apr;97(4):216-22. http://dx.doi.org/10.1016/j.prosdent.2007.02.013. PMid:17499091.

13. Bagis B, Turkarslan S, Tezvergil-Mutluay A, Uctasli S, Vallittu PK, Lassila LV. Effect of ultrasonic agitation on bond strength of self-etching adhesives to dentin. J Adhes Dent. 2008 Dec;10(6):441-5. PMid:19189674.

14. Alexandre RS, Sundfeld RH, Giannini M, Lovadino JR. The influence of temperature of three adhesive systems on bonding to ground enamel. Oper Dent. 2008 May-Jun;33(3):272-81. http://dx.doi.org/10.2341/07-79. PMid:18505217.

15. Watanabe T, Tsubota K, Takamizawa T, Kurokawa H, Rikuta A, Ando S, et al. Effect of prior acid etching on bonding durability of single-step adhesives. Oper Dent. 2008 Jul-Aug;33(4):426-33. http://dx.doi.org/10.2341/07-110. PMid:18666501.

16. Perdigão J, Lopes MM, Gomes G. In vitro bonding performance of self-etch adhesives: II. ultramorphological evaluation. Oper Dent. 2008 Sep-Oct;33(5):534-49. http://dx.doi.org/10.2341/07133. PMid:18833860.

17. Lima AF, Silva VB, Soares GP, Marchi GM, Aguiar FHB, Lovadino JR. Influence of previous acid etching on interface morphology and bond strength of self-etching adhesive to cavosurface enamel. Eur J Dent. 2012 Jan;6(1):56-62. http://dx.doi.org/10.1055/s-0039-1698931. PMid:22229008.

18. Van Meerbeek B, Kanumilli P, De Munck J, Van Landuyt K, Lambrechts P, Peumans M. A randomized controlled study evaluating the effectiveness of a two-step self-etch adhesive with and without selective phosphoric acid etching of enamel. Dent Mater. 2005 Apr;21(4):375-83. http://dx.doi.org/10.1016/j.dental.2004.05.008. PMid:15766585.

19. Ermis RB, Temel UB, Celik EU, Kam O. Clinical performance of a two-step self-etch adhesive with additional enamel etching in Class III cavities. Oper Dent. 2010 Mar-Apr;35(2):147-55. http://dx.doi.org/10.2341/09-089-C. PMid:20420057. 
20. Silva e Souza MH Jr, Carneiro KGK, Lobato MF, Silva e Souza PA, Góes MF. Adhesive systems: important aspects related to their composition and clinical use. J Appl Oral Sci. 2010 May-Jun;18(3):207-14. http://dx.doi.org/10.1590/S1678-77572010000300002. PMid:20856995.

21. Yoshida Y, Nagakane K, Fukuda R, Nakayama Y, Okazaki O, Shintani H, et al. Comparative study on adhesive performance of functional monomers. J Dent Res. 2004 Jun;83(6):454-8. http://dx.doi.org/10.1177/154405910408300604. PMid:15153451.

22. Couto AM, Alevato AB, Andrade CO, Devito KP, Salvio LA. Análise da microinfiltração de restaurações em dentes posteriores hibridizados com adesivo autocondicionante após armazenagem. Rev Port Estomatol Med Dent Cir Maxilofac. 2016 Jan-Mar;57(1):46-50. http://dx.doi.org/10.1016/j.rpemd.2015.12.004.

23. Condon JR, Ferracane JL. Reduced polymerization stress through non- bonded nanofiller particles. Biomaterials. 2002 Sep;23(18):3807-15. http://dx.doi.org/10.1016/S0142-9612(02)00099-6. PMid:12164184.

24. Yuan Y, Shimada Y, Ichinose S, Tagami J. Qualitative analysis of adhesive interface nanoleakage using FE-SEM/EDS. Dent Mater. 2007 May;23(5):561-9. http://dx.doi.org/10.1016/j.dental.2006.03.015. PMid:16765432.

25. Coppini EK, Prieto LT, Pierote JJA, Araújo CTP, Oliveira DCRS, Paulillo LAMS. Influence of enamel acidetching on mechanical properties and nanoleakage of resin composite after aging. Braz J Oral Sci. 2018 Mar;16:1-10. http://dx.doi.org/10.20396/bjos.v16i0.8650500.

\section{CONFLICTS OF INTERESTS}

The authors declare no conflicts of interest.

\section{${ }^{*}$ CORRESPONDING AUTHOR}

João Victor Frazão Câmara, USP - Universidade de São Paulo, Faculdade de Odontologia de Bauru, Alameda Doutor Octávio Pinheiro Brisolla, 9-75, 17012-901 Bauru - SP, Brasil, e-mail: jvfrazao92@hotmail.com 